\title{
Major Parietal Cell Antigen in Autoimmune Gastritis with Pernicious Anemia is the Acid-producing $\mathrm{H}^{+}, \mathrm{K}^{+}$-Adenosine Triphosphatase of the Stomach
}

\author{
F. Anders Karlsson, * Pia Burman, * Lars Lööf, * and Sven Mårdh" \\ *Department of Internal Medicine, University Hospital, Uppsala, Sweden; and ${ }^{\ddagger}$ Department of Medical and Physiological Chemistry, \\ University of Uppsala, Sweden
}

\begin{abstract}
In autoimmune gastritis antibodies against a membrane-bound parietal cell antigen of previously unknown function are present in the sera of patients. In this study, a vesicular membrane preparation of porcine gastric mucosa cells was found to be a potent antigenic source. This preparation blocked $>90 \%$ of antibody binding to a lysate of gastric mucosa cells. The membrane fraction contained $\mathrm{H}^{+}, \mathrm{K}^{+}$-ATPase (EC 3.6.1.36) as the major protein, which in sodium dodecyl sulfate-polyacrylamide gel electrophoresis migrated with a weight of $92 \mathrm{kD}$. After reduction and alkylation, this component was resolved into two bands of similar staining intensity ( 92 and $88 \mathrm{kD}$ ). Immunoblotting analysis showed that sera of patients recognized antigen with pattern identical to the major protein of the vesicular membranes.

Protein A-Sepharose beads preincubated with immunoglobulins of five individual patient (but not control) sera were all found to reduce both the $\mathrm{H}^{+}, \mathrm{K}^{+}$-ATPase activity and the amount of parietal cell antigen of a preparation of vesicular membranes solubilized in $\boldsymbol{n}$-octylglucoside. Taken together, the results of this study indicate that the major parietal cell antigen is identical to the acid-producing enzyme, $\mathrm{H}^{+}, \mathrm{K}^{+}$-ATPase, of the parietal cell.
\end{abstract}

\section{Introduction}

Autoimmune gastritis (chronic gastritis type A) is characterized by a disturbed parietal cell function resulting in a reduced gastric acid production (1). In advanced stages of the disease, achlorhydria and mucosal atrophy in the gastric body and fundus are found. Apart from producing acid, the parietal cells also secrete intrinsic factor (2), the $60-\mathrm{kD}$ glycoprotein (3), which is essential for vitamin $B_{12}$ absorption. Deficiency of this vitamin results in pernicious anemia and neurological symptoms.

The pathogenesis of autoimmune gastritis seems to involve an immune-mediated destruction of the parietal cells. This is evidenced by a lymphocytic infiltrate in the mucosa, which consists predominantly of B cells (4), and by the production of autoantibodies $(1,5)$. Injection of patient IgG into rats reduces the gastric acid output and may induce atrophy of the mucosa (6). This suggests that the autoantibodies have a key role in the

Address reprint requests to Dr. Karlsson, Dept. of Internal Medicine, University Hospital, S-751 85 Uppsala, Sweden. 1987.

Received for publication 17 April 1987 and in revised form 5 August

J. Clin. Invest.

(c) The American Society for Clinical Investigation, Inc.

0021-9738/88/02/0475/05 \$2.00

Volume 81, February 1988, 475-479 expression of the disease. The antibodies are directed against a protein localized in the canalicular areas of the cell (7). Since the function of this protein has remained elusive, we have made attempts to disclose its physiological role.

In the present study we have identified the parietal cell protein that seems to serve as the major antigen in autoimmune gastritis. This molecule is identical to the acid-producing enzyme, $\mathrm{H}^{+}, \mathrm{K}^{+}$-ATPase (EC 3.6.1.36), of parietal cells.

\section{Methods}

Patient sera and immunoglobulin preparations. Sera from ten patients, six women and four men, ages 35-82 yr (mean age 61 yr), with a diagnosis of pernicious anemia and low vitamin B 12 levels, were used. The subjects had impaired vitamin B 12 absorption by a Schilling test, which was normalized after addition of intrinsic factor. Eight patients had been further investigated and found to have achyli/hypochyli and/or atrophic fundic gastritis. All sera were positive in a routine immunofluorescence test for parietal cell antibodies. Control sera were obtained from healthy individuals lacking parietal cell antibodies. IgG were prepared by ammonium sulfate $(1.6 \mathrm{M})$ precipitation of sera, followed by extensive dialysis against $20 \mathrm{mM}$ Tris- $\mathrm{HCl}$ buffer, $\mathrm{pH}$ 7.4. The final concentration of the IgG preparations ranged between 10 and $15 \mathrm{mg} / \mathrm{ml}$, as determined by the method of Lowry et al. (8).

Preparation of gastric mucosa cells, parietal cells, and vesicular membrane fractions. Porcine gastric mucosa cells were prepared by consecutive digestions with pronase and collagenase. Parietal cells were obtained by further purification of mucosa cells by centrifugation on Percoll gradients and elutriation $(9,10)$. The purity of parietal cell fractions was $\sim 90 \%$. Tubulovesicular membranes were prepared after homogenization of gastric mucosa and sucrose-Ficoll gradient centrifugation (11). A porcine kidney membrane preparation containing $\mathrm{Na}^{+}, \mathrm{K}^{+}$-ATPase was obtained as described elsewhere (12).

Parietal cell antibody assays. Parietal cell antibodies were measured in patient sera by routine indirect immunofluorescence analysis using fixed sections of rat stomach. An ELISA was developed to determine antibody binding to gastric mucosa cells and vesicular membranes. Flat-bottomed microtiter plates (Nunc, Copenhagen, Denmark) were coated overnight at $+4^{\circ} \mathrm{C}$ with $100-\mu$ l aliquots of porcine gastric mucosa cells $\left(2 \times 10^{6}\right.$ cells; $0.5 \mathrm{mg}$ protein, lysed in $100 \mu 10.2 \%$

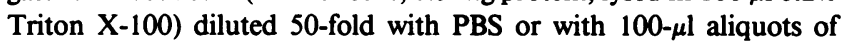
vesicular membranes diluted in PBS. Subsequently, the wells were washed four times with $250 \mu$ l PBS with $0.5 \%$ vol/vol Tween 20 (PBS-T). ${ }^{1}$ Then, 100- $\mu$ l aliquots of patient sera diluted 1:200 in PBS-T were added and incubated for $1 \mathrm{~h}$ at room temperature followed by four washes. Subsequently, $100 \mu \mathrm{l}$ of $\beta$-galactosidase conjugated rabbit anti-human IgG (Pharmacia Fine Chemicals, Uppsala, Sweden) was added. After $1 \mathrm{~h}$ at room temperature the wells were washed four times. A substrate solution containing $100 \mu \mathrm{l}$ of ortho-nitrophenyl- $\beta$-galactoside (Pharmacia Fine Chemicals) was added for $30 \mathrm{~min}$ at room temperature. The reaction was stopped with $100 \mu \mathrm{l} 0.66 \mathrm{M} \mathrm{Na}_{2} \mathrm{CO}_{3}$ and the absorbance measured at $405 \mathrm{~nm}$.

PAGE experiments. Antigen preparations were separated by electrophoresis in polyacrylamide gels, $4 \%$ stacking and $8 \%$ separating gels,

1. Abbreviations used in this paper: PBS-T, PBS with $0.5 \%$ Tween 20 ; PBS-t, PBS with $0.05 \%$ Tween 20. 
in Tris-glycine buffer with SDS (SDS-PAGE) as described by Laemmli (13). The antigen preparations were analyzed nonreduced, as well as after reduction ( $0.2 \mathrm{M} \beta$-mercaptoethanol) and alkylation $(0.2 \mathrm{M}$ iodoacetamide). Protein staining of the gels was performed with Coomassie Blue R-250.

In immunoblotting experiments the separated proteins were transferred after electrophoresis onto nitrocellulose membranes $(0.45 \mu \mathrm{m}$ pore size; Bio-Rad Laboratories, Richmond, CA) for $16 \mathrm{~h}$ at $200 \mathrm{~mA}$. The membranes were blocked by incubation in 1\% BSA-PBS for 30 min, washed twice in PBS-t for $30 \mathrm{~min}$, incubated with dilutions of patient and control sera in PBS-t for $60 \mathrm{~min}$, and washed twice in PBS-t followed by incubation with a 1:200 dilution of horseradish peroxidase rabbit anti-human IgG conjugate (Dakopatts $A B$, Hägersten, Sweden) in PBS-t buffer for $60 \mathrm{~min}$. The blots were washed twice in PBS-t and then incubated with a solution containing 4-chloro-1naphtol (color development reagent, Bio-Rad Laboratories) to detect antibody binding to the blots (14). All incubations and washes were carried out at room temperature.

Solubilization procedure. A vesicular membrane preparation (7.2 $\mathrm{mg}$ protein $/ \mathrm{ml}$ ) was solubilized with $1.3 \%$-octylglucoside (Boehringer Mannheim Biochemicals, Mannheim, FRG) at $4^{\circ} \mathrm{C}$ for $30 \mathrm{~min}$ followed by centrifugation at $70,000 \mathrm{~g}$ for $1 \mathrm{~h}$. The solubilizate $(6.8 \mathrm{mg}$ protein $/ \mathrm{ml}$ ), when tested for ATPase, showed reduced enzyme activity (15) estimated to be $5 \%$ of the native preparation.

Adsorption experiments. Protein A (1 mg) conjugated to Sepharose beads (Pharmacia Fine Chemicals) were preincubated at $37^{\circ} \mathrm{C}$ for 60 min with IgG preparations ( $1.5 \mathrm{mg}$ protein) of sera from patients with autoimmune gastritis and from healthy controls, respectively. The amounts of IgG bound to the protein A-Sepharose beads were the same with patient or control preparations. After washing in fresh buffer ( $20 \mathrm{mM}$ Tris- $\mathrm{HCl}, \mathrm{pH} 7.4$ ), $35 \mu \mathrm{g}$ of solubilized membranes in $0.16 \%$ $n$-octylglucoside was added and incubated for $1 \mathrm{~h}$ at $37^{\circ} \mathrm{C}$. The mixture was centrifuged $(2,000 \mathrm{~g})$ and $150 \mu \mathrm{l}$ of the supernatant ( $5 \mu \mathrm{g}$ protein) was analyzed for ATPase activity by incubation in a buffer containing $5 \mu \mathrm{M}^{32} \mathrm{P}$-labeled ATP ( $\left.25000 \mathrm{CPM}\right), 2 \mathrm{mM} \mathrm{MgSO}_{4}, 10 \mathrm{mM} \mathrm{KCl}$,

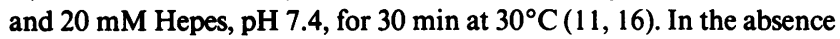
of $\mathrm{K}^{+}$in the incubation buffer $\leq 5 \%$ of the total ATPase activity remains (11). The amount of ${ }^{32} \mathrm{PO}_{4}$ formed was quantitated as an ammonium molybdate complex extracted into an isobutanol/toluene (1:1) phase. In the absence and presence of added enzyme, 0.8 and $8.2 \%$ of the ATP substrate was hydrolyzed, respectively. IgG-coated beads caused a nonspecific, $\sim 40 \%$, reduction of the enzyme activity, possibly in part due to residual ammonium ions in the IgG solutions.

The supernatants were also analyzed for the presence of parietal cell antigen. This was accomplished by measuring inhibition in an antibody binding assay. Microtiter plates precoated with a preparation of porcine vesicular membranes $(0.4 \mu \mathrm{g} /$ well $)$ were incubated with 25 $\mu \mathrm{l}$ of supernatants, together with a $1: 10,000$ dilution of a patient serum with a high titer ( $>1: 400$ as determined by routine immunofluorescence testing) of parietal cell antibodies. Subsequently, the inhibitory effect of the different supernatants on antibody binding was determined by the ELISA described above.

Statistics. Experimental data were analyzed for statistical signifcance by the unpaired $t$ test.

\section{Results}

In initial experiments the binding of antibody to microtiter wells, which were coated with lysates of gastric mucosa cells, was determined. Marked antibody binding was observed with sera of patients with autoimmune gastritis (Fig. 1, left). The mean \pm SD absorbance at $405 \mathrm{~nm}$ of 10 patient sera was $0.39 \pm 0.12$, compared with $0.19 \pm 0.06$ for sera of 10 healthy controls $(P<0.0005)$. In subsequent experiments, fractions of mucosa cells were examined for antigenicity. The antigen is known to be membrane bound (7) and a preparation of vesicu-
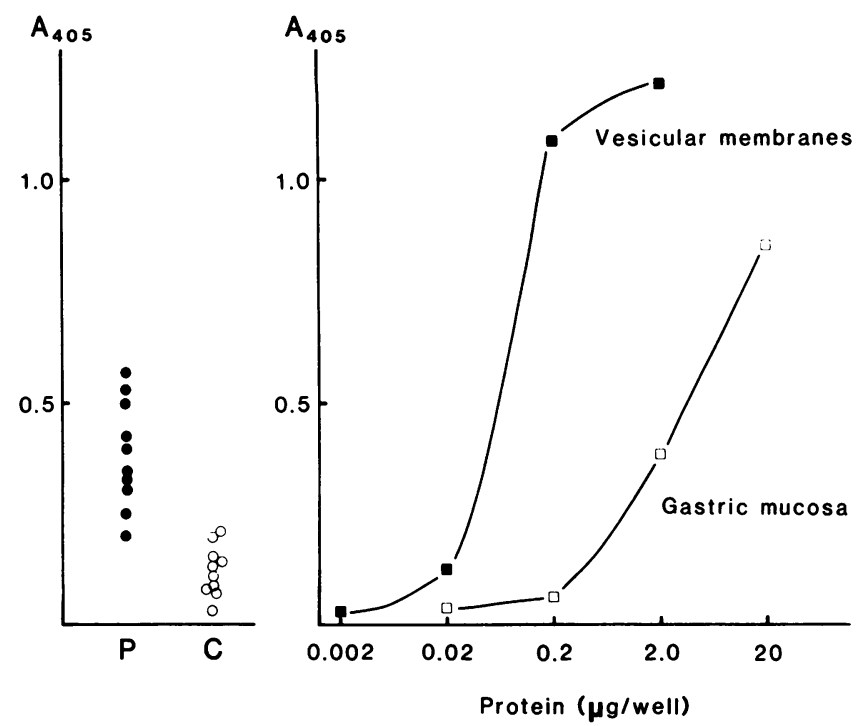

Figure 1. (Left) Antibody binding of sera of 10 patients with autoimmune gastritis (P) and 10 healthy controls (C) to microtiter wells coated with a lysate of porcine gastric mucosa cells ( $2 \mu \mathrm{g}$ per well). (Right) Binding of parietal cells antibody to microtiter wells coated with varying amounts of a lysate of gastric mucosa cells and a preparation of vesicular membranes, respectively. A pool of 10 sera of patients with autoimmune gastritis was used. Binding was detected by an enzyme-linked immunosorbent procedure as described in Methods. $\mathrm{A}_{\mathbf{4 0 5}}$, absorbance at $405 \mathrm{~nm}$.

lar membranes isolated from gastric mucosa cells was found to be $\sim 100$-fold more potent than mucosa cell lysates (Fig. 1, right). In a separate experiment the capacity of vesicular membranes to inhibit parietal cell antibody binding to gastric mucosa cell lysates was studied. More than $90 \%$ of antibody binding was blocked by high concentrations of gastric vesicular membranes, whereas porcine kidney membrane preparations, rich in $\mathrm{Na}^{+}, \mathrm{K}^{+}$-ATPase, did not affect antibody binding (Fig. 2). These data thus indicated that gastric vesicular membranes contain the major autoantibody binding material.

Further experiments were conducted to characterize the parietal cell antigen. When subjected to SDS-PAGE under

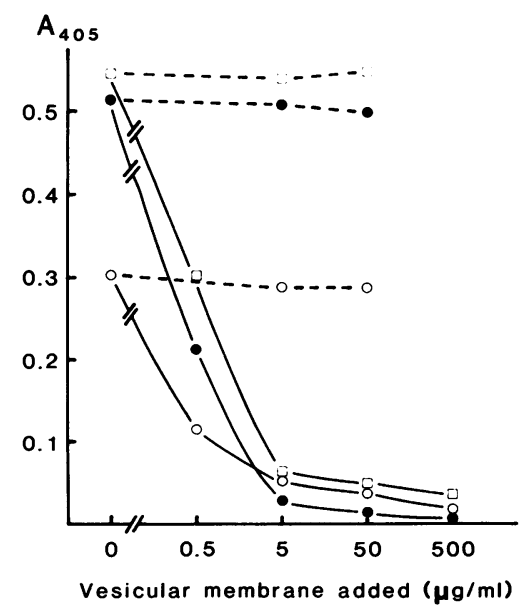

Figure 2. Inhibition of parietal cell antibody binding to a gastric mucosa cell lysate by gastric vesicular membranes (solid lines) and a preparation of porcine kidney membranes rich in $\mathrm{Na}^{+}, \mathrm{K}^{+}$-ATPase (broken lines). Two patient sera ( $\square$ and $O$ ) as well as a pool of 10 different patient sera $(\bullet)$, all diluted 1:200, were preincubated at $+4^{\circ} \mathrm{C}$ overnight with the different membranes. Subsequently, the solutions were examined for antibody binding. The microtiter plate had been precoated with $10 \mu \mathrm{g}$ protein per well. $A_{405}$, absorbance at $405 \mathrm{~nm}$. 
nonreducing conditions, multiple protein bands of gastric parietal cell preparations were stained (Fig. 3). A specific immunoblot signal of $92 \mathrm{kD}$ was always obtained in a position with only a minor amount of protein staining. In some experiments, weak nonspecific bands, corresponding to the major protein components of mucosa cell lysates, were observed with both patient and control sera. In the vesicular membrane preparation, one major protein band with an approximate molecular weight of $92 \mathrm{kD}$ was present. Upon immunoblotting analysis of nonreduced material, the antigen was localized in most experiments mainly to a $92-\mathrm{kD}$ band (Figs. 3 and 4). In some instances, however, a blurred, broad band of 65-75 kD was seen in addition to the $92-\mathrm{kD}$ band (Fig. 4). The basis of this variable behavior of nonreduced material upon immunoblotting analysis was not further explored.

After reduction ( $0.2 \mathrm{M} \beta$-mercaptoethanol) and alkylation of the vesicular membranes, the immunoblotting results were reproducible. The major antigen appeared in two sharp bands of similar intensity with weights $\sim 92$ and $88 \mathrm{kD}$ (Fig. 4). These bands were also seen in the protein staining, indicating that the parietal cell antigen corresponded to the major protein present in the vesicular membrane fraction. After reduction with high concentration (1M) of $\beta$-mercaptoethanol, the 92-kD material appeared as a $88-\mathrm{kD}$ band, and in addition as a broad band of lower mobility $\sim 100-105 \mathrm{kD}$. With low concentration of the agent $(0.002 \mathrm{M})$ a minor amount of the $88-\mathrm{kD}$ band was found, the $92-\mathrm{kD}$ band being the major component. Again, in these experiments the immunoblotting patterns corresponded to the major protein stainings (data not shown).

When vesicular membranes solubilized in $n$-octylglucoside were incubated with protein A-Sepharose beads precoated with five patient or five control IgG, all patient immunosor-

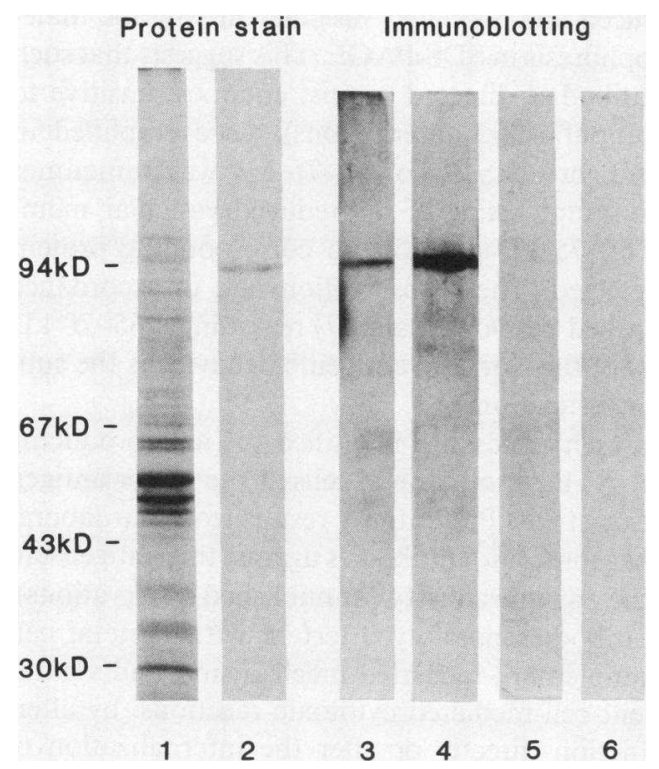

Figure 3. Analysis by SDS-PAGE and immunoblotting of gastric mucosa cells (lanes 1,3, and 5) and vesicular membranes (lanes 2, 4, and 6 ) treated under nonreducing conditions. 50 and $5 \mu \mathrm{g}$ protein, respectively, were applied in the lanes. Protein staining by Coomassie Blue (lanes 1 and 2) and immunoblotting with a pool of 10 sera of patients with autoimmune gastritis (lanes 3 and 4 ) and sera of healthy controls (lanes 5 and 6). Mobilities of molecular weight marker proteins are given to the left.

\section{Protein stain Immunoblotting}

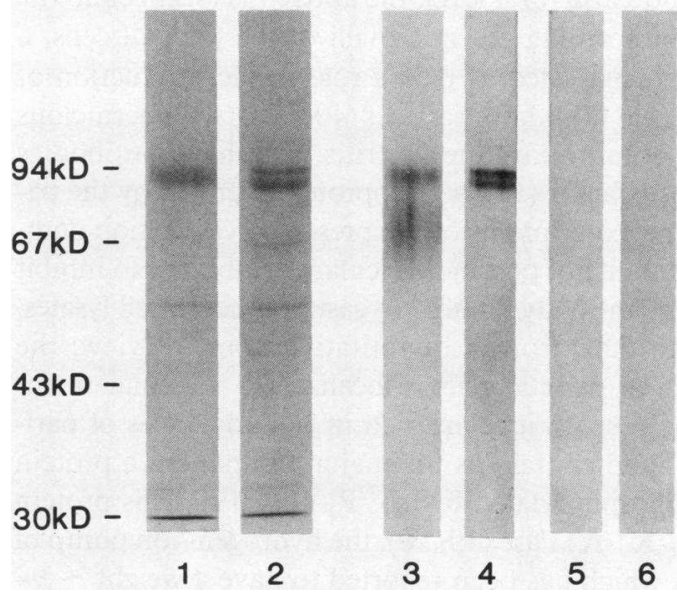

Figure 4. Analysis by SDS-PAGE and immunoblotting of vesicular membranes treated under nonreducing conditions (lanes 1, 3, and 5) after reduction and alkylation (lanes 2, 4, and 6). Protein staining and sera as in Fig. 3.

bent beads caused a reduction of the solubilized enzyme activity compared with the control beads (Fig. 5). Further, when examined by competitive inhibition experiments by ELISA, supernatants (containing the nonadsorbed material) from incubations with the five patient immunoglobulin beads blocked antibody binding by $35 \pm 13 \%$ (mean \pm SD) compared with $83 \pm 14 \%(P<0.005)$ determined with the five supernatants from the control beads. The data of these experiments (Fig. 5) likewise indicated that parietal cell antibodies of the patient sera were directed against the $\mathrm{H}^{+}, \mathrm{K}^{+}$-ATPase proper.

\section{Discussion}

In this study we found that vesicular membranes of porcine gastric corpus mucosa contain the major antigen recognized by antibodies of patients with autoimmune gastritis. A majority $(75-95 \%)$ of these patients have antibodies in serum against a particulate component of the cytoplasm of gastric parietal cells (17). Baur, Roitt, and Doniach reported in 1965 that the parietal cell antigen was associated with lipoproteins of a mi-

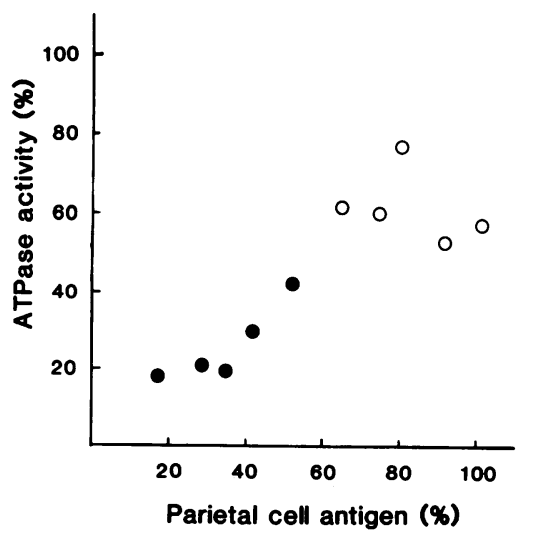

Figure 5. Immunodepletion of ATPase activity and parietal cell antigen of vesicular membranes. The membranes were solubilized in $0.16 \%$ n-octylglucoside and incubated with protein A-Sepharose beads, which had been preincubated with immunoglobulin preparations of sera from five patients with autoimmune gastritis $(\bullet)$ and from five normal individuals (o). After incubation, the mixtures were centrifuged and the supernatants assayed for ATPase activity and parietal cell antigen as described in Methods. 
crosomal fraction of homogenates of human gastric mucosa (18). At the ultrastructural level, the antigen is localized to the cell membrane forming the microvilli of the parietal cells, a part of the cell suggested to play a role in the production of hydrochloric acid (7). Many patients (40-60\%) with pernicious anemia, due to autoimmune gastritis, also have antibodies against intrinsic factor (17), a glycoprotein secreted by the parietal cells. The experiments of the present investigation demonstrated the ability of porcine vesicular membranes to inhibit the majority of antibody binding to gastric mucosa cell lysates. This indicates that, from a quantitative point of view, the major antigen of parietal cells is localized to vesicular membranes. These preparations are rich in tubulovesicles of parietal cells (11) and contain as the major component a protein that can be phosphorylated by $\left[\gamma^{-32} \mathrm{P}\right]$ ATP (19). This protein represents $\mathrm{H}^{+}, \mathrm{K}^{+}$-ATPase $(19,20)$, the hydrogen-ion pump of the stomach, which has been reported to have a weight $\sim 94$ $\mathrm{kD}$ in its subunit form $(11,15)$. Recently, a complete nucleotide sequence of a cDNA clone of the rat stomach $\mathrm{H}^{+}, \mathrm{K}^{+}$ATPase, corresponding to a $114-\mathrm{kD}$ protein, was described (21). In the present study a weight of $92 \mathrm{kD}$ was determined for the major porcine parietal cell antigen in the nonreduced state. We have obtained similar data with a preparation of tubulovesicles of human origin (unpublished observations). Upon reduction and alkylation, two separate bands of 92 and $88 \mathrm{kD}$ emerged. These bands had similar intensity in protein staining and were equally antigenic in immunoblotting experiments, suggesting that the bands may represent two different populations of the enzyme subunit. Apparently, these two proteins are not disulfide linked, but reduction and alkylation affects intrachain reactive group/groups. The parallelism between major protein staining and immunoblotting patterns in experiments with membrane material was considered of prime importance as the results indicated identity between the major protein $\left(\mathrm{H}^{+}, \mathrm{K}^{+}\right.$-ATPase $)$of the gastric vesicles and the parietal cell antigen. The details of the reactions taking place after reduction and alkylation, as well as the basis for the molecular weight differences between the different bands, will be the subject of further studies.

Vesicular membranes containing $\mathrm{H}^{+}, \mathrm{K}^{+}$-ATPase can be solubilized by detergents such as $n$-octylglucoside and cholate $(22,23)$. After solubilization enzymatic activity is associated with higher molecular weight forms thought to reflect tetrameric, trimeric, and dimeric forms of the protein in addition to monomeric material (23). Solubilization is accompanied by a gradual loss of enzymatic activity. In the present study, $\sim 5 \%$ of the original enzyme remained in $0.16 \% n$-octylglucoside. Solubilizates containing monomeric enzyme regain enzymatic activity when added to liposome preparations (22). In this study, solubilized vesicular membranes were used to investigate direct antibody binding. Solubilized enzymatic activity was found to bind to antibody-coated protein A-Sepharose beads, which similarly bound parietal cell antigen. The data thus further demonstrate the identity between $\mathrm{H}^{+}, \mathrm{K}^{+}$-ATPase and the major parietal cell antigen, as suggested by the electrophoresis and immunoblotting experiments.

Autoimmune gastritis is accompanied by a reduced gastric acid production and a gradual loss of the gastric mucosa, which is infiltrated by a large number of lymphocytes, mainly B cells (4). Injection of IgG from patients into experimental animals results in reduced acid production and mucosal atrophy (6). A direct inhibitory effect of patient IgG on acid secre- tion of bull frog gastric mucosa in vitro has been reported, as well as an inhibition of gastrin-stimulated carbonic anhydrase activity as analyzed by a cytochemical assay (24). Further, gastrin receptor blocking antibodies have been described by the use of a radioreceptor assay with isolated parietal cells and by inhibition of gastrin stimulation of aminopyrine accumulation in parietal cells (25), an indirect index of $\mathrm{HCl}$ production (26). In this latter study, gastrin receptor antibodies were detected only in a fraction of patients with pernicious anemia, whereas all patients studied had parietal cell antibodies. These investigators reported a $65-70-\mathrm{kD}$ protein, albeit not detectable in protein staining, as the presumptive microsomal antigen in pernicious anemia. The antigen was identified by immunoblotting analysis using patient sera and parietal cell homogenates from rat and dog or gastric microsomes from mouse, dog, and rat (27). The protein appeared antigenic only in sulfhydryl nonreduced state. Further, a second, distinct protein of $\sim 88 \mathrm{kD}$ was also reported to react, but less well than the $65-70-\mathrm{kD}$ band, with parietal cell microsomal antibodies. This protein was detected only with dog mucosa and appeared antigenic only in sulfhydryl reduced form.

Our results and interpretation of electrophoretic and immunoblotting experiments are at variance with those of Dow et al. (27). In our opinion, the major parietal cell antigen is the protein band of $92 \mathrm{kD}$ typically found with nonreduced material and the two sharp bands of 92 and $88 \mathrm{kD}$ present after reduction and alkylation of vesicular membranes. The antigenicity of this material, in the nonreduced as well as reduced and alkylated forms, was demonstrated with the use of pooled patient sera. Identical results were obtained when several individual sera were tested (not shown). However, we have noted that certain patient sera, despite being positive for parietal cell antibody by immunofluorescence and reactive against native vesicular membranes in ELISA, do not give an immunoblot signal with reduced and alkylated vesicular membrane material after electrophoresis in SDS-PAGE. This suggests that such sera contain antibodies directed against epitopes sensitive to denaturation (unpublished observations). As exemplified in Fig. 4, a blurred, broad band of $65-75 \mathrm{kD}$ was sometimes found upon immunoblotting of nonreduced vesicular membranes. In the $65-75 \mathrm{kD}$ position no corresponding protein staining was detected. These observations are in accordance with those described by Dow et al. (27) regarding a 65-70-kD band. The basis of this variable antigenic behavior is the subject of further investigation.

Thus, the present study has identified the acid-producing enzyme, $\mathrm{H}^{+}, \mathrm{K}^{+}$-ATPase, of parietal cells as the major antigen in autoimmune gastritis. Preliminary results from our laboratory indicate that some autoantibodies against this antigen can directly block the enzyme activity (unpublished observations). Parietal cell antibodies possibly interfere with parietal cell function via complement-mediated mechanisms, and via antibody-dependent cell-mediated cytotoxic reactions, by altering cellular function directly or after the internalization of membrane-bound antibodies. Patients with autoimmune gastritis may perhaps have, as discussed above, antibodies against the gastrin receptor, in addition to antibodies against the major parietal cell antigen. The extent to which $\mathrm{H}^{+}, \mathrm{K}^{+}$-ATPase antibodies and gastrin receptor antibodies occur simultaneously, and the separate roles of such antibodies in provoking inhibition of gastric acid production and cellular atrophy in patients with autoimmune gastritis, remains to be clarified. 


\section{Acknowledgments}

We are indebted to Majstin Lundberg, Matti Olsson, Tomas Björkman, and Charlotte Carlsson for providing excellent technical assistance.

This study was supported by grants from the Swedish Medical Research Council (projects 4996 and 4965), AB Hässle, MöIndal, Sweden, and Svenska Livförsäkringsbolags nämnd för medicinsk forskning, SK\&F Research Grant for Nordic Gastroenterology, Swedish Society of Medicine.

\section{References}

1. Strickland, R. G., and I. R. Mackay. 1973. A reappraisal of the nature and significance of chronic atrophic gastritis. Am. J. Dig. Dis. 18:426-440.

2. Levine, J. S., P. K. Nakane, and R. H. Allen. 1980. Immunocytochemical localization of human intrinsic factor: the nonstimulated stomach. Gastroenterology. 79:493-502.

3. Gräsbeck, R., K. Simons, and I. Sinkkonen. 1966. Isolation of intrinsic factor and its probable degradation product, as their vitamin B 12 complexes, from human gastric juice. Biochim. Biophys. Acta. 127:47-58.

4. Kaye, M. D., P. J. Whorwell, and R. Wright. 1983. Gastric mucosal lymphocyte subpopulations in pernicious anemia and normal stomach. Clin. Immunol. Immunopathol. 28:431-440.

5. Glass, G. B. J. 1977. Immunology of atrophic gastritis. NY State J. Med. 77:1697-1706.

6. Tanaka, N., and G. B. J. Glass. 1970. Effect of prolonged administration of parietal cell antibodies from patients with atrophic gastritis and pernicious anemia on the parietal cell mass and hydrochloric acid output in rats. Gastroenterology. 58:482-494.

7. Hoedemaeker, P. J., and S. Ito. 1970. Ultrastructural localisation of gastric parietal cell antigen with peroxidase-coupled antibody. $L a b$. Invest. 22:184-188.

8. Lowry, O. H., N. J. Rosebrough, A. L. Farr, and R. J. Randall. 1951. Protein measurement with the Folin phenol reagent. J. Biol. Chem. 193:265-275.

9. Mårdh, S., L. Norberg, M. Ljungström, L. Humble, T. Borg, and C. Carlsson. 1984. Preparation of cells from pig gastric mucosa. Isolation of parietal cells by isopycnic centrifugation on linear density gradients of Percoll. Acta Physiol. Scand. 122:607-613.

10. Soll, A. H. 1978. The actions of secretagogues on oxygen uptake by isolated mammalian parietal cells. J. Clin. Invest. 61:370-380.

11. Ljungström, M., L. Norberg, H. Olaisson, C. Wernstedt, F. V. Vega, G. Arvidson, and S. Mårdh. 1984. Characterization of protontransporting membranes from resting pig gastric mucosa. Biochim. Biophys. Acta. 769:209-219.

12. Mårdh, S. 1979. Phosphorylation by the catalytic subunit of protein kinase of a preparation of kidney $\mathrm{Na}, \mathrm{K}-\mathrm{ATPase}$. In $\mathrm{Na}, \mathrm{K}$ ATPase, Structure and Kinetics. J. C. Skou and J. G. Nørby, editors. Academic Press, Inc., New York. 359-370.

13. Laemmli, U. K. 1970. Cleavage of structural proteins during assembly of the head of bacteriophage T4. Nature (Lond.). 227:680685 .

14. Hawkes, R., E. Niday, and J. Gordon. 1982. A dot-immunobinding assay for monoclonal and other antibodies. Anal. Biochem. 199:142-147.

15. Soumarmon, A., F. Grelac, and M. J. M. Lewin. 1983. Solubilization of active $\left(\mathrm{H}^{+}-\mathrm{K}^{+}\right)$-ATPase from gastric membrane. Biochim. Biophys. Acta. 732:579-585.

16. Mårdh, S. 1975. Bovine brain $\mathrm{Na}^{+}, \mathrm{K}^{+}$-stimulated ATP phosphohydrolase studied by a rapid-mixing technique. Biochim. Biophys. Acta. 391:448-463.

17. Irvine, W. J. 1975. Autoimmunity in endocrine disease. Clin. Endocrinol. Metab. 4:227-499.

18. Baur, S., I. M. Roitt, and D. Doniach. 1965. Characterization of the human gastric parietal cell auto-antigen. Immunology. 8:62-68.

19. Saccomani, G., H. B. Stewart, D. Shaw, M. Lewin, and G. Sachs. 1977. Characterization of gastric mucosal membranes. XI. Fractionation and purification of $\mathrm{K}^{+}$-ATPase-containing vesicles by zonal centrifugation and free-flow electrophoresis technique. Biochim. Biophys. Acta. 465:311-330.

20. Ganser, A. L., and J. Forte. 1973. $\mathrm{K}^{+}$-stimulated ATPase in purified microsomes of bullfrog oxyntic cells. Biochim. Biophys. Acta. 307:169-180.

21. Shull, G. E., and J. B. Lingrel. 1986. Molecular cloning of the rat stomach $\left(\mathrm{H}^{+}+\mathrm{K}^{+}\right)$-ATPase. J. Biol. Chem. 261:16788-16791.

22. Rabon, E., R. D. Gunther, A. Soumarmon, S. Bassilian, M. Lewin, and G. Sachs. 1985. Solubilization and reconstitution of the gastric H,K-ATPase. J. Biol. Chem. 260:10200-10207.

23. Sourmarmon, A., J. C. Robert, and M. J. M. Lewin. 1986. Depolymerization of solubilized $\left(\mathrm{H}^{+}+\mathrm{K}^{+}\right)$-ATPase by $n$-octylglucoside or cholate. Biochim. Biophys. Acta. 860:109-117.

24. Loveridge, N., L. Bitensky, J. Chayen, T. U. Hausamen, J. M. Fisher, K. B. Taylor, J. D. Gardner, G. F. Bottazzo, and D. Doniach. 1980. Inhibition of parietal cell function by human gammaglobulin containing gastric parietal cell antibodies. Clin. Exp. Immunol. 41:264-270.

25. De Aizpurua, H. J., B. Ungar, and B. H. Toh. 1984. Autoantibody to the gastrin receptor in pernicious anemia. N. Engl. J. Med. 313:479-483.

26. Berglindh, T., H. F. Helander, and K. J. Öbrink. 1976. Effects of secretagogues on oxygen consumption, aminopyrine accumulation, and morphology in isolated gastric glands. Acta Physiol. Scand. 97:401-414.

27. Dow, C. A., H. J. de Aizpurua, J. S. Pedersen, B. Ungar, and B. H. Toh. 1985. 65-70 kD protein identified by immunoblotting as the presumptive gastric microsomal autoantigen in pernicious anemia. Clin. Exp. Immunol. 62:732-737. 